\title{
PENGARUH MODEL PEMBELAJARAN INKUIRI TERBIMBING BERBANTUAN MEDIA KONKRET TERHADAP KOMPETENSI PENGETAHUAN IPA
}

\author{
Kadek Ayu Diah Ratna Sari ${ }^{1}$, Komang Ngurah Wiyasa ${ }^{2}$, Ni Nyoman Ganing ${ }^{3}$ \\ Jurusan Pendidikan Guru Sekolah Dasar \\ Universitas Pendidikan Ganesha \\ Singaraja, Indonesia \\ e-mail: sari.ayu15@undiksha.ac.id, kmwiasa@gmail.com,ninyoman.ganing@undiksha.ac.id
}

\begin{abstract}
Abstrak
Penelitian ini bertujuan untuk mengetahui perbedaan yang signifikan kompetensi pengetahuan IPA antara kelompok yang dibelajarkan melalui model pembelajaran Inkuiri Terbimbing berbantuan media konkret dengan kelompok yang dibelajarkan melalui pembelajaran konvensional pada siswa kelas IV SD Gugus Dewi Sartika Denpasar Timur tahun pelajaran 2017/2018. Populasi penelitian ini adalah seluruh siswa kelas IV SD Gugus Dewi Sartika Denpasar Timur tahun pelajaran 2017/2018. Sampel diambil dengan teknik random sampling dengan mengacak kelas. Sampel dalam penelitian ini adalah kelas IVB SD N 10 Kesiman sebagai kelompok eksperimen dan kelas IVB SD N 3 Kesiman sebagai kelompok kontrol dengan jumlah masing - masing kelompok eksperimen sebanyak 40 siswa dan kelompok kontrol sebanyak 41 siswa. Data yang dikumpulkan adalah data kompetensi pengetahuan IPA dan dianalisis dengan uji-t. Setelah dianalisis dengan uji-t, diperoleh $t_{\text {hitung }}=2,372$ pada taraf signifikansi $5 \%(\alpha=0,05)$ dengan $d k=79$ dan $t_{\text {tabel }}$ $(\alpha=0,05)=2,000$. Berdasarkan kriteria pengujian $t_{\text {hitung }}=2,372>t_{\text {tabel }}(\alpha=0,05)=2,000$. Hasil penelitian menunjukkan bahwa rata-rata gain skor kelompok eksperimen lebih besar dari kelompok kontrol dengan rata-rata $\bar{X}=0,41>\bar{X}=0,31$, dapat disimpulkan bahwa terdapat pengaruh model pembelajaran Inkuiri Terbimbing berbantuan Media Konkret terhadap kompetensi pengetahuan IPA. Dengan demikian, terdapat pengaruh yang signifikan kompetensi pengetahuan IPA kelompok yang dibelajarkan melalui model pembelajaran Inkuiri Terbimbing berbantuan Media Konkret dengan kelompok siswa yang dibelajarkan melalui pembelajaran konvensional pada siswa kelas IV SD Gugus Dewi Sartika Denpasar Timur tahun pelajaran 2017/2018.
\end{abstract}

Kata kunci: model pembelajaran inkuiri terbimbing, media konkret, kompetensi pengetahuan IPA

\begin{abstract}
The purpose of this study was to know the significant different in science knowledge between the group of students who were taught through Guided Inquiry Learning Model assissted by concrete media and the group of students who were taught through conventional learning model at grade IV students of SD Gugus Dewi Sartika Denpasar Timur in academic year 2017/2018. The population of this research was all fourth grade students of SD Gugus Dewi Sartika Denpasar Timur in academic year 2017/2018. The sampling was conducted by random sampling technique by randomizing class. The sample of this research was IV B of SD N 10 as experimental group and IV B of SD N 3 Kesiman as control group with the total number of experimental group was 40 students and the contol group was 41 students. The data collected was the data of the competency of science knowledge and analyzed by ttest. After being analyzed by t-test, obtained tcount $=2,372$ at significance level $5 \%$ $(\square=0,05)$ with $\mathrm{dk}=79$ and ttable $(\alpha=0,05)=2.000$. Based on the test value $\mathrm{t}_{\text {count }}=$ $2.372>t_{\text {table }}(\alpha=0,05)=2.000$. The results showed that experimental gained more score in compared to control group with mean of $\bar{X}=0,41>\bar{X}=0,31$, it can be concluded that there is an effect by implementing Guided Inquiry Learning Model toward science knowledge competence. Thus, there is a significant difference
\end{abstract}


between the science knowledge of the group which were taught through Guided Inquiry Learning Model assissted by Concrete Media and the group of students who were taught through conventional learning in IV grade students of SD Gugus Dewi Sartika East Denpasar in academic year 2017/2018.

Keywords : guided inquiry learning model, concrete media, science knowledge competence

\section{Pendahuluan}

Pendidikan memiliki peran yang sangat penting dalam membentuk individu menjadi Sumber Daya Manusia (SDM) yang berkualitas dan mampu menghadapi perkembangan Ilmu Pengetahuan dan Teknologi (IPTEK) serta menghadapi perkembangan dalam segala bidang kehidupan. Maka dari itu pendidikan sangat perlu untuk dikembangkan diberbagai ilmu pengetahuan, karena pendidikan yang berkualitas dapat meningkatkan kecerdasan suatu bangsa. Untuk mewujudkan itu semua diperlukan proses pembelajaran yang tersusun atas sejumlah komponen atau unsur yang saling berkaitan satu dengan lainnya. Interaksi antara guru dan siswa pada saat proses belajar mengajar memegang peran penting dalam mencapai tujuan yang diinginkan.

Sejauh ini proses pembelajaran masih berfokus kepada guru sebagai sumber utama pengetahuan, kemudian dengan kemajuan teknologi yang ada kurang dimanfaatkan oleh sebagian guru karena berbagai macam alasan, sehingga pada saat proses belajar mengajar guru kurang membangkitkan pengetahuan dan aktivitas siswa dalam mengikuti pelajaran. Pembelajaran yang terpusat pada siswa mengisyaratkan guru menjadi fasilitator dalam pembelajaran. Guru sebagai fasilitator diharapkan dapat menjembatani pemikiran siswa yang divergen dalam pemecahan masalah di dalam pembelajaran. Tugas seorang guru secara rinci tertuang pada Undang - Undang No. 14 Tahun 2005 tentang guru dan dosen yaitu sebagai berikut "Guru adalah pendidik profesional dengan tugas utama mendidik, mengajar, membimbing, mengarahkan, melatih, menilai dan mengevaluasi peserta didik pada pendidikan pada anak usia dini jalur pendidikan formal, pendidikan dasar, dan pendidikan menengah".

Tugas seorang guru tidak sebatas mengajar namun lebih kompleks dan menyangkut pula dalam membimbing sampai dengan mengevaluasi proses pembelajaran apakah sudah berhasil atau belum. Apabila seorang guru sudah mampu menjalankan tugasnya sebagai pendidik yang profesional, diharapkan pembelajaran dapat berhasil dengan hasil yang optimal. Salah satu hal yang perlu diperhatikan dalam pelaksanaan proses pendidikan adalah kurikulum. Berdasarkan Undang - Undang Nomor 20 Tahun 2016, "Kurikulum adalah seperangkat rencana dan pengaturan mengenai tujuan, isi, dan bahan pelajaran serta cara yang digunakan sebagai pedoman penyelenggaraan kegiatan pembelajaran untuk mencapai tujuan pendidikan tertentu." Kurikulum yang diterapkan saat ini adalah kurikulum 2013. Penerapan kurikulum 2013 merupakan salah satu upaya Kemendikbud dalam memperbaiki mutu pendidikan agar mampu menghasilkan lulusan yang siap bersaing secara global dimasa yang akan datang.

Kurikulum 2013 adalah salah satu upaya pemerintah untuk memperbaiki kualitas mutu pendidikan agar dapat mencetak manusia yang berkulitas dan mampu proaktif menjawab tantangan zaman yang selalu berubah. Pendidikan yang paling dasar ialah pada Sekolah Dasar (SD). Dalam permendikbud Nomor 57 tahun 2014 lampiran 1 menetapkan Kurikulum pada Sekolah Dasar yang telah dilaksanakan sejak tahun Pelajaran 2013/2014 disebut Kurikulum 2013 Sekolah Dasar. Pendidikan di SD sangat penting mengingat pada jenjang inilah siswa mulai dibentuk karakter, motivasi serta tingkah lakunya. Kurikulum 2013 dalam pembelajaran melibatkan sikap, pengetahuan dan keterampilan.proses IPA seperti mengamati, menanya, menumpulkan informasi, mengasosiasi, mengkomunikasikan, dan mencipta. Dalam melaksanakan hal tersebut sangat diperlukan bantuan dari guru. Akan 
tetapi bantuan guru tersebut harus semakin berkurang dengan semakin bertambahnya siswa atau semakin tingginya kelas siswa.

Proses pembelajaran pada Kurikulum 2013 untuk semua jenjang dilaksanakan dengan menggunakan pendekatan ilmiah (saintifik). Guru diharapkan sebagai motivator, fasilitator serta mediator apabila siswa mengalami kesulitan dalam proses pembelajaran. Guru tidak dimaksudkan untuk terpaku hanya pada buku serta tidak dimaksudkan untuk terpaku hanya pada buku penugasan maupun pembelajaran dikelas. Metode pembelajaran yang dipilih oleh seorang guru sangat mempengaruhi keinginan siswa dalam belajar. Guru yang terpaku hanya pada buku serta tidak memilih metode yang tepat mengakibatkan siswa merasa bosan dan tidak tertarik untuk mengikuti kegiatan belajar mengajar. Dari perjalanan guru membelajarkan siswa dengan pendekatan saintifik, guru merasa masih belum cukup mencapai pengetahuan belajar yang optimal dalam mata pelajaran IPA. Maka dari itu, dirasa perlu untuk mengkolaborasikan pendekatan saintifik dengan model pembelajaran yang inovatif salah satunya yaitu model pembelajaran inkuiri. Pembelajaran yang didapat siswa ketika belajar inkuiri adalah pengetahuan yang bermakna dan bersifat jangka panjang karena hasil konstruksi pengetahuan yang didapat selama pembelajaran dengan pengetahuan awal siswa.

Selama ini dikenal ada tiga macam model pembelajaran inkuiri, 1) inkuiri terbimbing (guided inkuiri). 2) inkuiri bebas (free inkuiri). 3) inkuiri yang bebas dimodifikasi (modified free inkuiri). Berdasarkan dari uraian ketiga jenis model pembelajaran inkuiri, model inkuiri terbimbing akan digunakan dalam penelitian ini.pemilihan ini dilakukan dengan pertimbangan bahwa penelitian yang akan dilakukan terhadap siswa kelas IV SD, dimana siswa belum berpengalaman belajar dengan model inkuiri bebas, sehingga dirasa model inkuiri terbimbing lebih cocok untuk digunakan.

Menurut Khoirul Anam (2015), Siswa bekerja (bukan hanya duduk, mendengarkan lalu menulis) untuk menemukan jawaban terhadap masalah yang dikemukakan oleh guru di bawah bimbingan yang intensif dari guru. Tugas guru lebih seperti memancing siswa untuk melakukan sesuatu. Guru datang ke kelas dengan membawa masalah untuk di pecahkan oleh siswa, kemudian mereka dibimbing untuk menemukan cara terbaik dalam memecahkan masalah tersebut. Model pembelajaran inkuiri terbimbing berorientasi pada altivitas kelas yang berpusat pada siswa dan memungkinkan siswa belajar memanfaatkan berbagai sumber belajar yang tidak hanya menjadikan guru sebagai sumber belajar. Siswa secara aktif akan terlibat dalam proses mentalnya melalui kegiatan pengamatan, pengukuran, dan pengumpulan data untuk menarik suatu kesimpulan. Dalam model pembelajaran inkuiri terbimbing siswa secara aktif dalam proses pembelajaran yaitu mulai dari perencanaan, pelaksanaan, sampai proses evaluasi. Dengan menerapkan pembelajaran berbasis inkuiri akan memacu keingintahuan siswa dalam menemukan hal-hal yang ingin diketahui siswa.

IImu Pengetahuan Alam (IPA) merupakan pembelajaran berdasarkan pada prinsip prinsip, proses yang mana dapat menumbuhkan sikap ilmiah siswa terhadap konsep konsep IPA. Pembelajaran IPA di sekolah dasar dilakukan dengan penyelidikan sederhana dan bukan hafalan terhadap kumpulan konsep IPA. Melalui kegiatan - kegiatan tersebut pembelajaran IPA akan memberikan pengalaman secara langsung melalui pengamatan, diskusi, dan penyelidikan sederhana serta menumbuhkan sikap ilmiah siswa yang di indikasikan dengan merumuskan masalah, menarik kesimpulan, sehingga mampu berpikir kritis melalui pembelajaran IPA.

Model pembelajaran akan lebih sempurna apabila didukung dengan penggunaan media pembelajaran, salah satunya dengan memanfaatkan media konkret (Melistyana,2017). Media konkret merupakan sekelompok media tanpa proyeksi yang menyajikan secara visual tiga dimensional. Media ini dapat berwujud benda asli, baik hidup maupun mati dan dapat pula berwujud sebagai tiruan yang mewakili aslinya (Daryanto, 2011:27). Berdasarkan hal tersebut, menggunakan media konkret dapat menjadi pilihan yang tepat bagi guru untuk menciptakan suasana belajar yang aktif, kreatif, menarik dan tidak membosankan bagi siswa. 
Hasil pengamatan yang dilakukan pada hari Rabu tanggal 10 Januari 2018. Permasalahan yang ditemukan di Gugus Dewi Sartika Denpasar Timur adalah belum optimalnya penguasaan kompetensi pengetahuan IPA siswa kelas IV dilihat dari nilai yang masih dibawah KKM kurang dari 70 . Selain itu ada beberapa masalah yang muncul saat pembelajaran antara lain masih banyak siswa yang bermain-main saat pelajaran sedang berlangsung, hal ini dikarenakan siswa mengalami kebosanan. Selama ini kegiatan yang dilakukan siswa pada saat proses belajar lebih banyak hanya mendengar apa yang disampaikan guru. Komunikasi yang terjadi adalah komunikasi satu arah, yaitu guru kepada siswa.

Berdasarkan uraian sebelumnya maka diuji cobakan model pembelajaran Inkuiri Terbimbing berbantuan media konkret untuk dapat mencapai pengetahuan belajar yang optimal dalam mata pelajaran IPA dan mengkaji lebih luas tentang permasalahan yang telah ditemukan di Sekolah Dasar melalui penelitian yang berjudul "Pengaruh Model Pembelajaran Inkuiri Terbimbing Berbantuan Media Konkret Terhadap Kompetensi Pengetahuan IPA Siswa Kelas IV SD Gugus Dewi Sartika Tahun Pelajaran 2017/2018".

Berdasarkan uraian tersebut, maka penelitian ini bertujuan untuk mengetahui: (1) deskripsi kompetensi pengetahuan IPA kelompok siswa yang dibelajarkan dengan model pembelajaran Inkuiri Terbimbing berbantuan Media Konkret, (2) deskripsi kompetensi pengetahuan IPA kelompok siswa yang dibelajarkan konvensional dan (3) perbedaan yang signifikan kompetensi pengetahuan IPA antara kelompok siswa yang dibelajarkan dengan model pembelajaran inkuiri terbimbing dan kelompok siswa yang dibelajarakan secara konvensional pada siswa kelas IV Gugus Dewi Sartika Denpasar Timur tahun pelajaran 2017/2018.

Manfaat praktis dalam penelitian ini dapat memberi manfaat bagi pihak-pihak sebagai berikut. (a) Model pembelajaran yang digunakan dalam penelitian dapat diterapkan oleh guru sebagai suatu stratgi pembelajaran,sehingga pembelajaran IPA menjadi lebih bermakna dalam kehidupan siswa sehari-hari. (b) Penelitian ini dapat bermanfaat untuk meningkatkan aktivitas siswa dalam belajar dan mampu meningkatkan kompetensi pengetahuan IPA. (3) Hasil penelitian ini dapat mengungkapkan perbedaan kompetensi penegetahuan IPA antara siswa yang dibelajarkan menggunakan model pembelajaran Inkuiri Terbimbing berbantuan Media Konkret dengan siswa yang dibelajarkan secara konvesional pada siswa kelas IV SD Gugus Dewi Sartika tahun pelajaran 2017/2018. Selain itu, penelitian ini dapat memberikan pengalaman langsung kepada peneliti sebagai calon guru dalam menerapkan model pembelajaran yang inovatif.

\section{Metode}

Penelitian ini merupakan penelitian eksperimen semu (kuasi eksperimen) yang dilaksanakan di SD yang ada di Gugus Dewi Sartika Denpasar Timur. Populasi penelitian adalah seluruh siswa kelas IV SD Gugus Dewi Sartika yang terdiri dari 12 kelas dalam 6 sekolah dasar. Jumlah siswa kelas IV di gugus tersebut adalah 366 siswa. Sampel diambil dengan teknik random sampling. Teknik random sampling yang dimaksud dalam penelitian ini adalah dengan menggunakan undian. Hal ini memungkinkan setiap kelas memperoleh hak atau kesempatan yang sama untuk terpilih menjadi sampel penelitian.

Setelah diketahui bahwa seluruh kelas IV di SD Gugus Dewi Sartika tidak terdapat kelas unggulan atau semua kelas dinyatakan setara, maka pengundian sudah dapat dilakukan. Cara pengundian ini adalah dengan menuliskan seluruh nama kelas IV di seluruh SD populasi pada kertas dan menggulungnya. Kemudian letakkan semua gulungan pada sebuah wadah. Lakukan pengundian dengan mengeluarkan dua gulungan dari wadah secara bergantian. Dua gulungan kertas tersebut adalah sampel dari penelitian.

Selanjutnya, kedua kelas tersebut diberikan pretest untuk mengetahui kesetaraan dengan menggunakan uji t. Sebelum melakukan uji t, perlu dilakukan uji prasyarat yang meliputi uji normalitas dan uji homogenitas. Setelah kedua kelas tersebut dinyatakan setara, 
maka tahap selanjutnya adalah melakukan pengundian kembali untuk memilih kelas yang akan digunakan sebagai kelas eksperimen dan kelas kontrol.

Kesetaraan sampel diuji dengan rumus uji t yakni dengan polled varian bila $n 1 \neq n 2$ varians homogen dengan derajat kebebasan $(\mathrm{dk})=\mathrm{n} 1+\mathrm{n} 2-2$. Bila $\mathrm{n} 1=\mathrm{n} 2$ varians homogen, maka dapat digunakan rumus t test dengan separated varian maupun polled varian dengan derajat kebebasan $(\mathrm{dk})=\mathrm{n} 1+\mathrm{n} 2-2$.

Kriteria pengujiannya adalah jika $t_{\text {hitung }}>t_{\text {tabel }}$, maka $\mathrm{H}_{\circ}$ ditolak dan $\mathrm{H}_{\mathrm{a}}$ diterima. Sebaliknya $t_{\text {hitung }} \leq t_{\text {tabel }}$ maka $\mathrm{H}_{\mathrm{o}}$ diterima dan $\mathrm{H}_{\mathrm{a}}$ ditolak, pada taraf signifikan $5 \%$ dengan $\mathrm{dk}$ $=\mathrm{n} 1+\mathrm{n} 2-2$

Berdasarkan perhitungan hasil uji normalitas nilai pretest kelompok eksperimen $\mathrm{X}^{2}$ hitung $=0,024$ dan $X_{\text {tabel }}^{2}(\alpha=0,05)=0,189$, karena $X^{2}$ hitung $=0,024<X^{2} t_{\text {abel }(\alpha=0,05)}=0,189$ maka data berdistribusi normal. Perhitungan hasil uji normalitas nilai pretest kelompok eksperimen selengkapnya dapat dibaca pada lampiran hal. Berdasarkan perhitungan hasil uji normalitas nilai pretest kelompok kontrol $X^{2}{ }_{\text {hitung }}=0,056$ dan $X_{\text {tabel }(\alpha=0,05)}^{2}=0,191$, karena $X^{2}{ }_{\text {hitung }}=0,056$ $<\mathrm{X}_{\text {tabel }(\mathrm{a}=0,05)}^{2}=0,191$ maka data berdistribusi normal.

Berdasarkan analisis uji normalitas, berikut ini disajikan rekapitulasi hasil uji homogenitas kelompok eksperimen dan kelompok kontrol dengan menggunakan uji $F$. Berdasarkan uji homogenitas $F_{\text {hitung }}=1,26$ dan $F_{\text {tabel }}(\alpha=0,05)=1,70$ karena $F_{\text {hitung }}=1,26<$ $F_{\text {tabel }}(\alpha=0,05)=1,70$ maka data homogen. Karena data nilai pretest kedua kelompok berdistribusi normal dan homogen dilanjutkan dengan melakukan uji kesetaraan dengan uji-t. Berdasarkan hasil analisis didapat $t_{\text {hitung }}=0,0248$ dan $t_{\text {tabel }}$ pada taraf signifikasi $5 \%$ dengan derajat kebebasan $d k=(n 1+n 2-2)=2,000$. Sehingga $t_{\text {hitung }}=0,0248<t_{\text {tabel }}(\alpha=0,05)$ $=2,000$. Berdasarkan uji-t kesetaraan yang telah dilakukan diperoleh bahwa kedua kelas tersebut setara.

Untuk menentukan kelompok eksperimen dan kelompok kontrol. Kelas yang muncul pertama saat diundi dijadikan sebagai kelompok eksperimen, sedangkan kelas yang muncul kedua dijadikan sebagai kelompok kontrol. Berdasarkan hasil undian, diperoleh kelas IV SDN 10 Kesiman berjumlah 40 siswa yang muncul pertama dijadikan sebagai kelompok eksperimen dan kelas IV SDN 3 Kesiman berjumlah 41 siswa yang muncul kedua dijadikan sebagai kelompok kontrol. Pada kelas eksperimen diberikan perlakuan dengan model pembelajaran Inkuiri Terbimbing berbantuan Media Konkret dan kelas kontrol diberikan perlakuan pembelajaran secara konvensional.

\begin{tabular}{|ccc|}
\hline $\mathrm{O}_{1}$ & $\mathrm{X}$ & $\mathrm{O}_{2}$ \\
\hdashline $\mathrm{O}_{3}$ & - & $\mathrm{O}_{4}$ \\
\hline
\end{tabular}

(Sumber : Sugiyono,2014:89)

Keterangan :

O1 = Pre Test pada kelas eksperimen

$\mathrm{O} 3=$ Pre Test pada kelas kontrol

$\mathrm{O} 2=$ Post Test pada kelas eksperimen. (Kompetensi pengetahuan kelompok Eksperimen yang telah diberi treatment Model Pembelajaran Inkuiri Terbimbing Berbantuan Media Konkret).

O4 = Post Test pada kelas kontrol. (Kompetensi pengetahuan kelompok Kontrol yang telah diberikan Pembelajaran Konvensional).

$\mathrm{X}=$ Treatment atau perlakuan. 
Prosedur penelitian ini terdiri atas beberapa tahapan, yang dipaparkan sebagai berikut. 1) Tahap Persiapan Eksperimen, a.Melakukan observasi dan wawancara dengan kepala Gugus Dewi Sartika Denpasar Timur serta wali kelas IV di setiap sekolah yang ada di Gugus Dewi Sartika Denpasar Timur untuk mengetahui ada atau tidaknya kelas unggulan di SD yang ada di Gugus Dewi Sartika Denpasar Timur.b.Mempersiapkan kurikulum dan silabus bersama wali yang terkait dengan materi yang akan diuji cobakan dalam penelitian ini.c.Menyusun RPP (Rencana Pelaksanaan Pembelajaran) beserta media pembelajaran dan LKS. d.Mempersiapkan pembelajaran dengan Model Pembelajaran Inkuiri Terbimbing Berbantuan Media Konkret yang akan digunakan untuk membelajarkan kelas eksperimen. e.Mengkonsultasikan instrumen penelitian pre test dan post test bersama wali kelas dan dosen pembimbing. f.Mengkonsultasikan RPP, LKS dan media pembelajaran bersama wali kelas dan dosen pembimbing. g.Mengadakan uji coba instrumen penelitian soal post test. h.Memberikan pre test kepada seluruh populasi untuk membuktikan kesetaraan kelompok. i.Analisis data pre test seluruh populasi dengan teknik uji t. j.Melakukan pengundian untuk menentukan kelompok eksperimen dan kelompok kontrol. 2) Tahap Pelaksanaan Eksperimen, a.Memberikan perlakuan pada kelas eksperimen dengan Model Pembelajaran Inkuiri Terbimbing Berbantuan Media Konkret. b.pada kelas kontrol dengan Pembelajaran Konvensional. c.Perlakuan diberikan sebanyak 6 kali di kelas eksperimen dan 6 kali juga di kelas kontrol. Jumlah perlakuan yang diberikan telah disesuaikan dengan jam pelajaran terkait materi dalam penelitian ini yang telah diatur dalam kurikulum dan silabus. d.Memberikan post test pada akhir penelitian, baik untuk kelompok eksperimen maupun kontrol.3) Tahap Akhir Eksperimen , a.Memberikan posttest pada akhir penelitian, untuk kelompok eksperimen maupun kontrol. b.Menganalisis data hasil penelitian. c.Melakukan uji hipotesis.

Instrumen pengumpulan data yang digunakan dalam penelitian ini adalah tes. Tes yang akan digunakan untuk mengukur penguasaan kompetensi pengetahuan IPA adalah berupa tes objektif dalam bentuk pilihan ganda biasa dengan 4 pilihan jawaban (a,b,c atau d) dengan jumlah pertanyaan yaitu 35 butir soal. Skor setiap jawaban dijumlahkan dan jumlah tersebut menjadi skor variabel penguasaan kompetensi pengetahuan IPA yang bergerak dari kisaran 0-35. 0 merupakan skor minimal dan 35 merupakan skor maksimal.

Instrumen yang digunakan dalam penelitian ini telah divalidasi oleh pakar (validitas konstruk). Selanjutnya, instrumen diujicobakan ke lapangan dan hasilnya dianalisis berdasarkan validitas butir tes, reliabilitas tes, daya pembeda soal, dan tingkat kesukaran butir soal.

Data yang telah diperoleh dari penelitian didiskripsikan menurut variabel kompetensi pengetahuan IPA siswa. Analisis statistik deskriptif menampilkan rata-rata, standar deviasi dan varians.

Sebelum dilakukan uji hipotesis, dilakukan uji prasyarat analisis, yang meliputi uji normalitas dan uji homogenitas. Dalam hal ini digunakan rumus polled varians karena jumlah anggota sampel tidak sama $(n 1 \neq n 2)$ dan varians homogen. Rumus polled varians dapat ditulis sebagai berikut.

$$
t=\frac{\overline{X_{1}}-\overline{X_{2}}}{\sqrt{\frac{\left(n_{1}-1\right) s_{1}^{2}+\left(n_{2}-1\right) s_{2}^{2}}{n_{1}+n_{2}-2}\left[\frac{1}{n_{1}}+\frac{1}{n_{2}}\right]}}
$$

(Sumber : Sugiyono,2017:138) 


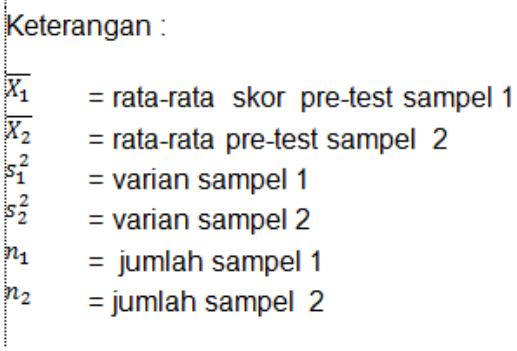

\section{Hasil dan Pembahasan}

Berdasarkan hasil analisis deskriptif kompetensi pengetahuan IPA rata-rata gain skor kelompok eksperimen lebih tinggi dibandingkan dengan kelompok kontrol dengan rata-rata $\bar{X}=0,41>\bar{X}=0,31$. Berdasarkan hasil perhitungan rata-rata gain skor kelompok eksperimen 0,41 kemudian dikonverensikan pada tabel PAN Skala Lima, diketahui kompetensi pengetahuan IPA siswa kelompok eksperimen berada pada kategori cukup baik. Sedangkan rata-rata gain skor kelompok kontrol 0,31 kemudian dikonverensikan pada tabel PAN Skala Lima, diketahui kompetensi pengetahuan IPA siswa kelas kontrol berada pada kategori cukup baik.

Berdasarkan uji prasyarat analisis data, diperoleh bahwa data kompetensi pengetahuan IPA siswa kelompok eksperimen dan kontrol adalah normal dan homogen. Hasil perhitungan menggunakan rumus Kolmogorov-Smirnov pada uji normalitas diperoleh kompetensi pemahaman IPA siswa yang dibelajarkan menggunakan model pembelajaran inkuiri terbimbing berdistribusi normal dengan harga nilai maksimum $\left|F_{\mathrm{T}}-\mathrm{F}_{\mathrm{S}}\right|=0,039<$ harga nilai tabel Kolmogorov-Smirnov $=0,189$, maka Ho diterima dan sebaran data gain skor ternomalisasi kompetensi pengetahuan IPA kelas eksperimen berdistribusi normal dan kelompok siswa yang dibelajarkan secara konvensional juga berdistribusi normal dengan harga nilai maksimum $|\mathrm{FT}-\mathrm{FS}|=0,068<$ harga nilai tabel Kolmogorov-Smirnov $=$ 0,191, maka Ho diterima dan sebaran data gain skor ternormalisasi kompetensi pengetahuan IPA kelas kontrol berdistribusi normal. Begitu pula dengan hasil uji homogenitas menggunakan uji $F$, varians data kompetensi pengetahuan IPA siswa antara kelompok siswa yang dibelajarkan menggunakan model pembelajaran inkuiri terbimbing dengan kelompok siswa yang dibelajarkan secara konvensional adalah homogen, yaitu Fhitung $=1,30<$ Ftabel $(\alpha=0,05)=1,70$.

Tabel 1. Hasil Uji Hipotesis

\begin{tabular}{lllllll}
\hline Sampel & Rata-Rata & Varians & $\mathbf{N}$ & $\mathbf{t}_{\text {hitung }}$ & $\mathbf{t}_{\text {tabel }}$ & Kesimpulan \\
\hline $\begin{array}{l}\text { Kelompok } \\
\begin{array}{l}\text { Eksperimen } \\
\text { Kelompok Kontrol }\end{array}\end{array}$ & 0,41 & 0,033 & 40 & 2,372 & 2,000 & $\mathrm{H}_{\circ}$ ditolak \\
\hline
\end{tabular}

Berdasarkan tabel tersebut, tampak bahwa $t_{\text {hitung }}$ sebesar 2,372 sedangkan $t_{\text {tabel }(\alpha=0,05)}=$ 2,000 . Hal ini berarti $t_{\text {hitung }}$ lebih besar dari $t_{\text {tabel }}$ sehingga $H_{0}$ ditolak. Dengan demikian, dapat disimpulkan bahwa terdapat perbedaan yang signifikan kompetensi pengetahuan IPA antara kelompok siswa yang dibelajarkan dengan model pembelajaran inkuiri terbimbing berbantuan media konkret dengan siswa yang dibelajarkan secara konvensional pada siswa kelas IV Gugus Dewi Sartika Denpasar Timur tahun pelajaran 2017/2018.

Rata - rata gain skor kompetensi pengetahuan IPA yang diperoleh kelompok yang dibelajarkan melalui model pembelajaran Inkuiri Terbimbing berbantuan media konkret lebih tinggi dari kelompok yang dibelajarkan melalui pembelajaran konvensional dengan 
perolehan $(\bar{X}=0,41>\bar{X}=0,31)$. Sehingga dapat disimpulkan bahwa model pembelajaran Inkuiri Terbimbing berbantuan media konkret berpengaruh terhadap kompetensi pengetahuan IPA siswa kelas IV SD Gugus Dewi Sartika Denpasar Timur tahun pelajaran 2017/2018.

Hasil analisis deskriptif menunjukkan bahwa rata-rata gain skor kompetensi pengetahuan IPA kelompok eksperimen, yaitu 0,41 lebih tinggi dari kelompok kontrol 0,31.

Pada kelompok eksperimen, kegiatan pembelajaran dalam muatan materi IPA menggunakan model pembelajaran Inkuiri Terbimbing berbantuan media konkret berjalan dengan baik. Siswa menjadi lebih aktif dalam kegiatan pembelajaran, siswa sangat antusias saat mengikuti kegiatan pembelajaran yang berhubungan dengan gaya dan gerak. Siswa mampu bekerja sama dengan kelompok dalam memecahkan masalah yang ditemukan. Dari berbagai kegiatan yang dilakukan, dapat terlihat bahwa siswa sangat termotivasi dan memiliki semangat belajar yang tinggi. Berbeda dengan kelompok kontrol, kegiatan pembelajaran hanya menggunakan pendekatan saintifik sehingga kurang berjalan dengan baik. Hal ini menyebabkan kurangnya keaktiffan dan antusias siswa dalam proses pembelajaran. Kurang bervariasinya penggunaan media pembelajaran menyebabkan siswa cepat bosan dalam belajar serta pada kelompok kontrol siswa cenderung bekerja sendiri dan tidak terdapat kekompakan, karena siswa tidak dibentuk dengan kelompok sehingga kurangnya kerjasama antarsiswa. Kegiatan pembelajaran mengguanakan model pembelajaran Inkuiri Terbimbing berbantuan media konkret memberikan hasil belajar khususnya dalam kompetensi pengetahuan IPA yang lebih tinggi pada siswa karena model pembelajaran Inkuiri Terbimbing berbantuan media konket memiliki kelebihan dalam kegiatan pembelajaran dengan mengajak siswa terkibat secara langsung dalam pemecahan masalah di kehidupan sehari-hari yang dipadukan dengan media konkret terkait dengan pembelajaran siswa di sekolah.

Menurut Suastra (2009) Inkuiri Terbimbing bertujuan untuk membantu siswa mengetahui sains, strategi pembelajaran yang berpusat pada siswa dimana kelompokkelompok siswa dihadapkan pada suatu persoalan atau mencari jawaban terhadap pertanyaan-pertanyaan melalui suatu prosedur yang direncanakan secara jelas.

Perbedaan hasil kompetensi pengetahuan IPA siswa dapat terlihat dari langkah pembelajaran yang dilakukan pada kedua kelompok tersebut, hasil analisis uji hipotesis, dan nilai rata-rata kelompok siswa yang mengikuti pembelajaran menggunakan menggunakan model pembelajaran Inkuiri Terbimbing berbantuan media konkret dengan siswa yang mengikuti pembelajaran konvensional.

Hal tersebut didukung hasil penelitian yang dilakukan oleh Puspawati (2013) bahwa terdapat perbedaan siswa yang dibelajarkan melalui pembelajaran Inkuiri Terbimbing berbantuan media konkret dengan siswa yang dibelajarkan melalui pembelajaran konvensional pada siswa kelas V SD Gugus V Kecamatan Buleleng. Dengan dengan demikian, model pembelajaran Inkuiri Terbimbing berbantuan media konkret dapat direkomendasikan dalam membelajarkan siswa khususnya pada kegiatan pembelajaran yang berisi muatan materi IPA.

\section{Simpulan dan Saran}

Berdasarkan hasil dari penelitian yang telah dilaksanakan maka dapat disimpulan sebagai berikut. 1) kompetensi pengetahuan IPA kelompok yang dibelajarkan melalui model pmbelajaran Inkuiri Terbimbing berbantuan media konkret pada siswa kelas IV SD Gugus Dewi Sartika Denpasar Timur tahun pelajaran 2017/2018 rata-rata gain skor 0,41. Dari data tersebut, kemudian dikonversikan pada PAN Skala Lima. Rata-rata kelompok eksperimen dapat dikategorikan cukup baik. 2) kompetensi pengetahuan IPA kelompok yang dibelajarkan melalui pembelajaran konvensional pada siswa kelas IV SD Gugus Dewi Sartika Denpasar Timur tahun pelajaran 2017/2018 diperoleh rata-rata gain skor 0,31. Dari data tersebut, kemudian dikategorikan pada PAN Skala Lima. Rata-rata kelompok kontrol dapat 
dikategorikan cukup baik. 3) berdasarkan hasil analisis menggunakan uji-t dengan dk=79 pada taraf signifikansi $5 \%$ diperoleh $t_{\text {hitung }}=2,372 \quad t_{\text {tabel }}=2,000$. Ini berarti bahwa terdapat perbedaan yang signifikan kompetensi pengetahuan IPA antara kelompok yang dibelajarkan melalui model pembelajaran Inkuiri Terbimbing berbantuan media konkret dengan kelompok yang dibelajarkan melalui pembelajaran konvensional pada siswa kelas IV SD Gugus Dewi Sartika Denpasar Timur tahun pelajaran 2017/2018 pada tema Daerah Tempat Tinggalku. Rata-rata gain skor kompetensi pengetahuan IPA yang diperoleh kelompok yang dibelajarkan melalui model pembelajaran Inkuiri Terbimbing berbantuan media konkret lebih tinggi dari kelompok yang dibelajarkan melalui pembelajaran konvensional $(x=0,41>x=0,31)$. Hal tersebut menyatakan bahwa terdapat pengaruh model pembelajaran Inkuiri Terbimbing berbantuan media konkret terhadap kompetensi pengetahuan IPA siswa kelas IV SD Gugus Dewi Sartika Denpasar Timur tahun pelajaran 2017/2018.

Berdasarkan hasil penelitian tersebut, beberapa saran yang dapat diajukan guna peningkatan kualitas pembelajaran di SD adalah sebagai berikut. 1) Kepada guru disarankan agar dapat dijadikan acuan dalam pemilihan model pembelajaran yang sesuai dengan Kurikulum 2013 dengan melihat karakteristik muatan pembelajaran yang terintegrasi dan sesuai dengan kebutuhan siswa. Kegiatan pembelajaran menjadi lebih menarik dan bervariasi karena dapat menggunakan model dan media pembelajaran yang tidak hanya terdapat di kurikulum 2013 saja. Salah satu model pembelajaran yang dapat disarankan, yaitu model pembelajaran Inkuiri Terbimbing berbantuan media konkret, terutama untuk kegiatan pembelajaran pada muatan materi IPA. 2) hendaknya sekolah dapat menciptakan kondisi yang mampu mendorong para guru untuk mencoba menerapkan model-model pembelajaran yang sesuai dengan karakteristik siswa dan sesuai kurikulum 2013, serta lebih kreatif dalam memilih model dan media pembelajaran yang digunakan dalam proses pembelajaran untuk meningkatkan kualitas pembelajaran di sekolah. 3) Peneliti lain supaya mampu menemukan model pembelajaran yang lebih inovatif dan bervariasi sesuai dengan Kurikulum 2013 dan proses pembelajaran agar dapat memotivasi siswa untuk mengikuti kegiatan pembelajaran pembelajaran dengan lebih baik dan menyenangkan.

\section{DAFTAR PUSTAKA}

Anam,Khoirul.2015.Pembelajaran Berbasis Inkuiri Metode dan Aplikasi.Yogyakarta:Pustaka Pelajar.

Kemendikbud. 2013. Permendikbud Nomor 57 Tahun 2014 Tentang Kurikulum Di Sekolah Dasar/ Madrasahlbtidaiyah.Jakarta:Kementrian Pendidikan dan Kebudayaan

Daryanto,Drs.2011. Media Pembelajaran. Yogyakarta: Gava Media

Suastra, I Wayan.2009. Pembelajaran Sains Terkini.Singaraja : Undiksha

Sugiyono, 2017. Statistik Untuk Penelitian. Bandung: Alfabeta

Sugiyono.2014. Metode Penelitian Administrasi dilengkapi dengan R\&B. Bandung: Alfabeta

Puspawati, Kt.2013. "Pengaruh Model Pembelajaran Inkuiri Terbimbing Berbantuan Media Konkret Terhadap Pemahaman Konsep IPA Siswa Kelas V SD Gugus V Kecamatan Buleleng". Jurnal Pendidikan dan Pengajaran, Volume 1, Edisi Mei (hlm.1-10) 